УДК $-33=30=111$

\title{
SPECIFICS OF ENGLISH ECONOMIC TERMINOLOGY TRANSLATION
}

\author{
S. B. KHRYSTIUK, PhD in World History, Associate Professor, \\ National University of Life and Environmental Sciences of Ukraine
}

E-mail: svitlana.khrystiuk@gmail.com

ORCID: 0000-0003-4119-8562

\begin{abstract}
Economic terms are considered to be one of the most dynamic parts of the lexical and semantic language system. Thus, taking into account that there are significant differences in the structure of the different countries economic systems, economic terms require the detailed study within one language and further comparison within two or more languages. The study is topical first of all because the problems of the economic terminology system development, its functioning, structural-semantic and linguistic features are extremely important both theoretically and practically, taking into account modern processes of Ukraine's international relations expansion and enhancement with the rest of the world. Currently, the English terminological units' reproduction optimization is the considerable importance issue for Interpretation and Translation Studies development. Among the main difficulties in translating English terms into Ukrainian is the discrepancy in terminology and lexical-grammatical, morphological structure of these languages. The most common translation transformations are use of full or fixed Ukrainian equivalent, calquing or wordfor-word translation, transliteration, transcription, descriptive translation.
\end{abstract}

Keywords: globalization processes, economic terminology, translation, terminology unit, equivalent, calquing, transliteration, transcription, descriptive translation

Introduction. The new century and the millennium coming opens up the immense and fascinating horizons to the world civilization. It integrates into a single holistic world system within the globalization spread framework. Consequently, this affects all living environments of humanity, including economy, politics, security, science and culture, directly concerning Ukraine as an integral part of the world order which plays a notable role in the new-fashioned international relations forming not only at the European level.

It should be noticed that the late nineteenth and early twentieth centuries is defined as the period of tech prosperity in Ukraine, this is the desire of young people to study abroad, to learn foreign languages, to start their own business, to communicate actively with foreign partners, this is a time of negotiations, conferences, seminars, workshops, and therefore it is a period of extensive translation activities as well as the desire for terms unification, overcoming linguistic barriers in various spheres of social and economic activity. We must admit that nowadays economic terms are actively developing in the Ukrainian language, therefore it is logical to assume that the results of human mental activity associated with the economy are fixed in terms.

Thus, the latest globalization development has determined the priority position of the English language as a means of communication between different peoples of the United Europe and the world. Nowadays, it is also true that the English language is the main source of the international economic terminology forming. It should be noted that economic terms are most commonly formulated in

(C) S. B. Khrystiuk

«International journal of philology» | «Міжнародний філологічний часопис» Vol. 10, № 1, 2019 
English or are borrowed through English as an intermediary language. Thus, taking into account that there are significant differences in the structure of the economic systems of different countries, economic terms require the detailed study within one language and further comparison within two or more languages.

Terminology is the most dynamic and moving lexical language system, therefore this field studies are namely historically oriented. The study is topical first of all because the problems of the economic terminology system development, its functioning, its structural and semantic and linguistic features are extremely important both theoretically and practically, taking into account modern processes of Ukraine's international relations expansion and enhancement with the rest of the world. Modern scientific translation studios are aimed at studying the factors influencing the choice of translation options and their relationship with the specifics of the translation language. Currently, the English terminological units' reproduction optimization is the considerable importance issue for Interpretation and Translation Studies development.

Analysis of recent research and publications. The translation terminological aspect is not separated from other translation fields, but it has its own specifics. According to E. Pyrkov, this aspect is understood to mean a translation that uses the terminology [6, p. 103]. The terms translation study is found in the works of such linguists: V. Karaban [3], V. Koptilov [5], A. Diakov [2], S. Vlakhov, A. Komarov, V. Kizim, A. Zaruma-Panskykh, P. Newmark, L. Venuti and others. The study of the terms transfer during the translation was carried out by scientists V. I. Karaban [2], N. G. Alexandrova, L. I. Borisova, V. P. Danylenko, and others. The translitology issues are followed in the works of such scholars as L.V. Savitska,
M. V. Makhinova, O. I. Boichuk, T. A. Krisanova, N. Yu. Dmitrakova and others.

Purpose of the academic paper. English economic terminology is numeric and branched, which may cause some difficulties while translating. Therefore, the purpose of our study is to identify the features and reveal methods of the economic terminology translation into the Ukrainian language, to make its complex analysis, to find ways for achieving adequacy and equivalence in translation, to determine the English economic terms translation methods that do not have the corresponding equivalents in the Ukrainian language, to study structural, semantic and stylistic features of economic terms in the translation aspect.

Methods of study. Materials and methods of study were determined by the material specific nature. During the study, the following methods such as analysis, synthesis, comparison, description, generalization, systematization were used. The presence of semantically identical or similar lexical units is established by means of comparativehistorical and synchronously-comparable methods, system and synchronicdiachronic analysis, the method of comparison.

Results of the research and their discussion. No society can exist without language: all peoples and every individual live in a linguistic environment. The level of scientific language development influences the intellectual social progress, indicates its national linguistic selfexpression. As we know, language is a system that can be in constant movement, so changes occur at all its levels. Its vocabulary enrichment is driven by the effect of extralinguistic factors. Vocabulary is particularly intensive at the turn of the historical epochs. The notion of economic terminology covers the terminology of such branch systems as finance, management, marketing, accounting, banking, and others. The economic 
terminological system is dynamically developing, it is in close contact with the social life and development, responds to the linguistic changes, conveys scientific information.

Economic terminology, as a system of economic phenomena and concepts operating in the economic spheres of legislation, business documentation and economics, is a significant and extremely important layer of any national language vocabulary. Attention to terminology and its development on the own linguistic basis, the state and depth of scientific study, its elaboration and compilation degree are indicators of the state development, national and economic consciousness. One of the basic economic terminology specifics is its practical understanding by all members of the linguistic community, as long as economic terms have not remained within the vocabulary designed for specific tasks. Economic terminology is a full-fledged part of the general linguistic vocabulary of modern Ukrainian literary language, which are more semantically distinct, it has a tendency to monosemy, strict regulation in use, and openness.

A term (Latin terminus - borderline, boundary) is an emotionally neutral word or phrase, which means a clearly defined special concept of any branch of science, technology, art, social life, etc., and is characterized not only stylistically, but also by a certain lexical isolation. Its main features are specific nature, denomination, systematic character, monosemy, synonymy and homonymy, stylistic neutrality, accuracy, conciseness, international character, sonority and derivative terms easiness. Thus, the termcontext interaction is extremely important for word meaning in the course of scientific economic texts conveying from English into Ukrainian [1, p. 58].

If a word is used as a term of another specific field of knowledge, it is also monosemantic, distinguished semantically from its meanings, which are terminologically nonfunctioning, as well as in the terminology, but in another field of knowledge. Thus, the term is a word characterized not only stylistically, but also by a certain isolation in the vocabulary and the concepts definition belonging to a specific field of knowledge [7, p. 155].

Nowadays, economic terminology can be classified into the following lexical and themantic groups [4, p. 30]: a) persons engaged in economic activity: shareholder, broker, manager, broker, helper, hedger, charterer; b) mathematical indicators: bank liquidity ratio, index of living cost, wage index; c) organizations involved in financial and economic activities: the International Bank for Reconstruction and Development, the European Investment Bank, the International Credit Insurance Association; d) economic processes: inflation, investment, lending, collection, ratification, indexation; e) regulatory documents and laws: the Bulletin of the foreign exchange rate, the Law of money circulation, the Law of holidays.

Originally, economic terminology is classified as follows: a) $19 \%$ of the financial and economic terminology are actually Ukrainian words (by the way, economic terminology is among the few systems that has so few own terms): debt, debtor, cost, netting, redemption, expenses, cash, money, income, debt, savings, loan, account, cash, duty, mortgage, employment, services, supplier, trade; b) $8 \%$ are the words-hybrids, that is, ones consisting of two roots, one of them is actually Ukrainian, the other one is borrowed: the drawer, holder of bill of exchange, the livestock bill, the grantor, the quasi-price, capital productivity, capital intensity, capital stock, Euromarkets; c) the remaining $73 \%$ is the vocabulary borrowed from different world languages.

Today it is evident that the unstable terminological traditions nature makes to borrow more than create itself. That is why

(C) S. B. Khrystiuk

«International journal of philology» | «Міжнародний філологічний часопис» Vol. 10, № 1, 2019 
we have a large number of Englishlanguage borrowings in various economic terminology fields [8]. Thus, for example, the terms budget, advance, deficit, balance, credit, offshore, asset have already become usual. However, some terms such as clearing, timing, endorsement, outsourcing, engineering, trader and many others traditionally require the special vocabulary interpretations.

At the same time economic terms are not homogeneous by their structure. They can be classified into the following groups: a) simple (one-word): cash, investing, business, advance, concern, company, prolongation, sponsor, price, fine; b) complex: bending, heat flow, pressure gauge; c) vocabulary formed by the appositive assembly: lottery-allegro, invoice, gross premiums, bank card issuer, or with a preposition of an attribute: gross profit, business plan, gross interest, gross income, solo bill; d) compiled (collocations): 1) two-components: balance of payments, premium shares, emission balance, tax return, nominal value, money laundering; 2) three components: card accounting system, payroll rates, counterclaims, guaranteed securities, profitability of equity capital; 3) four-components: maintenance of the power of the current enterprise, capital repairs of fixed assets, bonus system of wages; 4) five-components: the index of purchasing power of the monetary unit, the quota in the international monetary fund, the ratio of provision of interest on loans; d) abbreviations: $P C$ - personal computer; GDP - gross domestic product.

While translating terms, it is necessary to take into account the context of their use, since a certain term can serve different professional fields, and even within one field of knowledge may denote different concepts. Thus, the term "turnover" in accounting terminology means "товарообіг", "обсяг продаж», in agricultural chemistry - "обмін речовин", in the technical field - "передача майна", in business - "річний обсяг продажів". The term "performance" is also multifunctional and is used in the following disciplines: 1) audit; 2) stock exchange activities; 3) aviation medicine; 4) security; 5 ) accounting, etc. In general, as it is shown in the examples, the knowledge of the difference in lexical meanings, which depends on the economic field the word belongs to is vital.

Thus, having processed and analyzed economic terminology texts we singled out the following translation methods (transformations, strategies):

1. Use of full or fixed Ukrainian equivalent. Here are examples of full or fixed equivalent use: implements - засоби праці; money - гроші, грошова маса; procedure - технологічний процес; unemployment - безробітmя; storehouse - склад; solvency платоспроможність; production виробництво; obsolescence - моральне зношення; pawnshop - ломбард; collaboration - співпраця; price - ціна; pledge - застава; profitability прибутковість; consult - з'ясовувати думку, exchange rate - валютний курс; demand and supply - попит ma пропозиція; assets and liabilities активи та пасиви.

2. Calquing or word-for-word translation of the English terminology. Here are examples of calquing or word-forword translation use: substitution заміщення; surplus - надлишок; consumer preferences - уподобання споживачів; demand saturation насичення попиту; basic earnings per share - базовий дохід на одну акцію; revolving credit - револьверний кредuт; industrial spiral - інфрляційна спіраль; income effect - ефект доходу; bilateral contract - двосторонній контракт; shareholder's (stockholder's) meeting збори акціонерів; plastic card transaction - розрахункові сплати за допомогою пластикових карток. 
3. Transcription (a sound form borrowing of the source language term) and transliteration (a graphic form borrowing of the source language term). Here are examples of transcription or transliteration use: factoring факторинг; budget - бюджет; infrastructure - інфрраструктура; information - інфоормація; innovation інновація; ітроrt - імпорт; export експорт; hyperinflation - гіперінфрляція; embargo - ембарго; emission - емісія; service - cepвic; business - бізнес; dialogue - діалог; integration інтеграція; implementation імплементація, context - контекст, optimism - оптимізм.

4. Descriptive translation is used by an interpreter when the terminology does not have Ukrainian equivalent and is not even borrowed by calquing or transcribing. Of course, in this case, the conciseness and clarity of presentation which is characteristic of international economic documents, is lost. Here are examples of the descriptive translation use: going-outof-business sale - ліквідаційний розпродаж; listed company - компанія, акції якої продаються на фондовій біржі; publicly traded company компанія, акції якої продаються на позабіржовому ринку, written-downvalue method - облік із залишкової вартості; off-balance-sheet transaction - позабалансова операція; demarketing - заходи для зниження попиту на товар.

\section{Conclusions and perspectives.} Terminology as a set of terms is an integral part of any language vocabulary. The primary term function is to name and determine each specific phenomenon or subject in a specific field of science as accurately as possible. Existence of several different names for the same concept is undesirable, as it can lead to errors and inaccuracies.

Consequently, the issue of terms translation and economic dictionaries compilation continues to be one of the modern linguistics topical one. Recently, economic terminology systems have significantly increased. Therefore, the translator or interpreter must not only be fluent in English but at the same time be aware of specific translation field, because the terms meaning is closely related to the context, its content and specific nature, and may vary depending on the field of use. An adequate translation can be made only if these two conditions are effectively combined.

Structural, semantic, syntactic differences between the English-Ukrainian terms create difficulties in choosing the translation method or strategy. Therefore, experienced translators usually choose one or another translation transformation guided by the specific term context and sometimes combine all above-mentioned techniques in order to convey their lexical meaning accurately into the target language, while preserving the sound form and morpheme structure of the source terminology as far as possible.

\section{Список використаних джерел}

1. Багмут Й. А. Проблеми перекладу суспільно-політичної літератури українською мовою. Київ: Наукова думка, 2005. $201 \mathrm{C}$.

2. Д'яков А. С.,Кияк Т. Р.,Куделько З. Б. Основи термінотворення: семантичні та соціолінгвістичні аспекти.Київ: Вид. дім "KM Academia", 2000. 218 c.

3. Карабан В. I. Переклад з української мови на англійську мову. Навчальний посібник-довідник для студентів вищих закладів освіти. Вінниця: Нова книга, 2003. 608 с.

4. Ковальська Н. А. Становлення і розвиток української економічної термінології. Одеса : ОНЕУ, Ротапринт, 2012 p. 62 c.

5. Коптілов, В. Теорія і практика перекладу. Київ, 2003. 185 с.

6. Пырков Е. Г. Коммуникативные аспекты перевода и терминология

(C) S. B. Khrystiuk

«International journal of philology» | «Міжнародний філологічний часопис» Vol. 10, № 1, 2019 
(методическое пособие). Москва, 1992. 127 c.

7. Раєвська Н. М. Лексикологія англійської мови. Київ, 2001. 234 с.

8. Христюк С. Б., Шанаєва-Цимбал Л. О. До питання ролі запозичень в сучасній українській економічній термінології. Науковий вісник НУБіП України. 2017. Вип. 272. С. $96-103$.

\section{References}

1. Bagmut, Y. A. (2005). Problemy perekladu suspilno-politychnoi literatury ukrainskoiu movoiu [Problems of the social and political literature translation into Ukrainian]. Kyiv, 201.

2. Diakov, A. S., Kyiak T. R., Kudelko Z. B. (2000). Osnovy terminotvorennia: semantychni ta sotsiolinhvistychni aspekty [Fundamentals of Terminology: Semantic and Sociolinguistic Aspects]. Kyiv, 218.

3. Karaban, V. I., Mace J. (2003). Pereklad z ukrainskoi movy na anhliisku.
Navchalnyi posibnyk-dovidnyk dlia studentiv vyshchykh navchalnykh zakladiv osvity [Translation from the Ukrainian language into English. A manual for students of higher education institutions]. Vinnitsa, 608.

4. Kovalska, N. A. (2012). Stanovlennia i rozvytok ukrainskoi ekonomichnoi terminolohii [Formation and development of Ukrainian economic terminology]. Odesa, 62.

5. Koptilov, V. (2003). Teoriia i praktyka perekladu [Theory and Practice of Translation]. Kyiv, 185.

6. Pyrkov, E. H. (1992). Kommunikativnyie aspekty perevoda i terminolohiia [Communicative aspects of translation and terminology]. Moskva, 127.

7. Raievska, N. M. (2001) Leksykolohiia anhliiskoi movy [Lexicology of English]. Kyiv, 234.

8. Khrystiuk, S. B. (2017) Do pytannia roli zapozychen $v$ suchasnii ukrainskii ekonomichnii terminolohii [To the matter of role of borrowings in the modern Ukrainian economic terminology]. Kyiv, $96-103$.

\section{ОСОБЛИВОСТІ ПЕРЕКЛАДУ АНГЛІЙСЬКОЇ ТЕРМІНОЛОГІЧНОЇ ЛЕКСИКИ В ГАЛУЗІ ЕКОНОМІКИ}

\section{С. Б. Христюк}

Анотація. Стаття присвячена дослідженню феномена розвитку сучасної української економічної термінології, пошуку адекватних та ефрективних перекладацьких трансфрормацій, аналізу основних труднощів перекладу англомовних економічних термінів на українську мову. Доведено актуальність дослідження. Проаналізовано стан розробки наукової проблематики дослідження. Беручи до уваги специфріку та особливості економічної термінології з'ясовано, що термінологічна лексика $\epsilon$ добре структурованою системою термінологічних одиниць, схильною до постійного збагачення та величезної кількості іншомовних асимільованих та не асимільованих запозичень, таким чином, результати розумової діяльності людини, пов'язані з економікою, закріплюються в термінах. 3 огляду на те, що у структурі економічних систем різних держав є суттєві відмінності, економічні терміни потребують детального вивчення у межах однієї мови та порівняння у межах двох та більше мов. Проаналізовано специфрічні поняття терміносистем. Доведено, що на сучасному етапі розвитку перекладознавства особливої ваги набувають питання оптимізації шляхів відтворення термінологічних одиниць англійської мови, а тому пріоритетними способами перекладу англійської економічної лексики в галузі економіки $\epsilon$ переклад за допомогою усталеного еквівалента, калькування, транслітерація, транскрибування, використання описового еквівалента.

Ключові слова: глобалізаційні процеси, економічна термінологія, переклад, термінологічна одиниця, еквівалент, калькування, транслітерація, транскрибування, описовий переклад 